
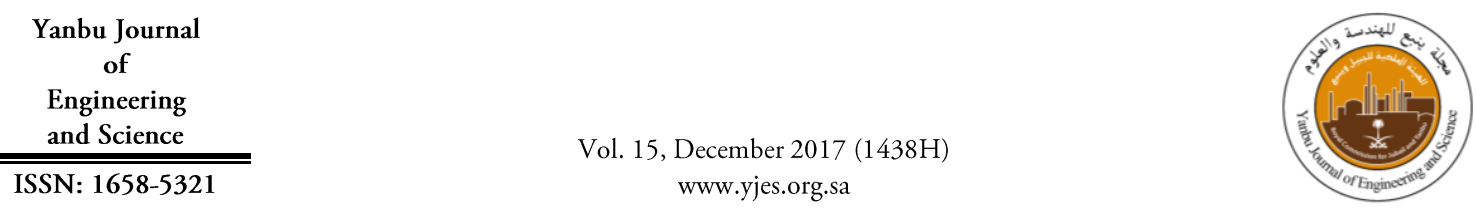

\title{
FRICTION BEHAVIOR OF CARBON FIBRES REINFORCED EPOXY FLOOR COATED BY POLYURETHANE AND SAND
}

\author{
Ali A. S. ${ }^{1}$ and Khashaba M. I. ${ }^{2}$ \\ ${ }^{1}$ Petrojet Company, Cairo, Egypt \\ ${ }^{2}$ Production Engineering and Mechanical Design Department, Faculty of Engineering, Minia University, Egypt \\ E-mail: eng_ahmed_youssef@hotmail.com
}

\begin{abstract}
Friction coefficient displayed by contact and separation as well as sliding when bare foot and foot wearing rubber contacting epoxy reinforced by carbon fibres (CF) and coated by polyurethane and sand particles is investigated. Generation of electrostatic charge (ESC) and its effect on friction coefficient will be discussed. It was found that ESC generated from contact and separation of PU coated by sand particles $\left(\mathrm{SiO}_{2}\right)$ and reinforced by CF recorded much higher values than PU and epoxy surfaces. Slight decrease in ESC was observed as the distance of CF from friction surface increased. ESC generated from sliding of PU coated by sand against bare foot displayed relatively higher values than that measured for epoxy and PU surfaces. Presence of sand increases friction coefficient due to the abrasive action of particles in bare foot surfaces which increases ESC. The penetration of sand particles into bare foot increases the contact area and hence increases ESC. Friction coefficient values recorded relatively higher values than that shown for epoxy and PU coating. ESC generated from contact and separation of rubber footwear and PU coated by sand displayed lower values than that observed for bare foot. In condition of sliding of PU coated by sand and reinforced by $\mathrm{CF}$ against rubber, it was found that ESC displayed values higher than that observed for contact and separation. The influence of sand was more pronounced during sliding than contact and separation. Friction coefficient decreased with increasing the distance of CF location from the surface. The friction values guaranteed the good adhesion required for floor materials.
\end{abstract}

Keywords: Friction coefficient, contact and separation, sliding, reinforced by carbon fibres, polyurethane coating.

\section{INTRODUCTION}

Materials that increase floor friction forces under foot pressure could reduce the risk of slipping and enhance walking safety. For reasons of technical design and economy, floor and floor systems in work places are often made from hard materials that do not deform under the pressure of the foot. There is an increasing demand to investigate proper solutions for reducing slip and fall accidents. The friction of footwear on floor coverings is responsible of the occurrence of slips and falls. The slip resistance is normally assessed on the bases of friction coefficient measured with footwear materials sliding 
against floors. The effect of rubber floor provided by cylindrical treads on the friction coefficient was investigated, [1]. Floor slipresistance is quantified by the static friction coefficient. In the USA, the static friction coefficient of 0.5 has been recommended as the slip-resistant standard for unloaded, normal walking conditions [2]. Higher the static friction coefficient values may be required for safe walking when handling loads. In Europe, [3], it was suggested that a floor was "very slip-resistant" if the friction coefficient was 0.3 or more. A floor with the friction coefficient between 0.2 and 0.29 was "slip resistant". A floor was classified as "unsure" if its friction coefficient was between 0.15 and 0.19. A floor was "slippery" and "very slippery" if the friction coefficient of was lower than 0.15 and 0.05 , respectively. The subjective ranking of floor slipperiness was compared with the static friction coefficient $(\mu)$ and found that the two measures were consistent, $[4,5]$. It was concluded that human subjects could discriminate floor slipperiness reliably. Many state laws and building codes have established that a static $\mu \geq 0.50$ represents the minimum slip resistance threshold for safe floor surfaces. Furthermore, the Americans with Disabilities Act Accessibility Guidelines [6] contain advisory recommendations for static friction coefficient of $\mu \geq 0.60$ for accessible routes (e.g. walkways and elevators) and $\mu \geq 0.80$ for ramps. The effect of surface roughness, on the friction behaviour of recycled rubber tiles, was discussed, [7]. Experiments were carried out by the sliding of the bare foot against the tested rubber tiles of different thickness. It was found that friction coefficient slightly increased with increasing the tile thickness. In the presence of water on the sliding surface, rough surface displayed higher friction values than the smooth one. The effect, of rectangular and cross treads introduced in the rubber mats on friction coefficient when sliding against footwear, was tested, [8]. It was found that friction coefficient slightly decreased with increasing tread groove at dry, detergent wet and oily sliding due to the decreased contact area accompanied to the increased groove width of the rubber. At water wet sliding friction coefficient remarkably increased with increasing the tread groove. Oily sliding displayed very low values of friction coefficient. As the tread width decreased the friction values decreased due to the decrease of the contact area at dry, detergent wet and oily sliding. Friction coefficient of rubber sliding against different types of floor materials of different surface roughness was investigated under different sliding conditions: dry, water, water/detergent dilution, oil, water/oil dilution, [9]. The floor materials are parquet, polyvinyl chloride (PVC), epoxy, marble, cement and ceramic. Based on the experiments, it was found out that at dry sliding, friction coefficient decreased with increasing surface roughness. Epoxy displayed relatively higher friction than parquet and PVC, while cement tiles gave the highest friction coefficient. Ceramic showed relatively lower friction values than marble and cement. The effect of floor materials, on the generation of electric static charge and friction coefficient, was discussed, [10]. Marble displayed higher values than that observed for ceramic floor. Based on this observation it can be suggested to select floor materials according to their resistance to generate electric static charge. Static friction coefficient displayed by rubber disc fitted by single groove sliding against ceramics was investigated, [11-14]. It was found that for dry sliding against 
ceramics, friction coefficient slightly increased with increasing load. For soft rubber friction coefficient slightly decreased with increasing normal load. In the presence of sand friction coefficient slightly decreased with increasing applied load. The effect of sand particles, on friction coefficient displayed by rubber sliding against ceramic tiles, was investigated, [15]. It was found that, at dry sliding, dust particles caused drastic decrease in friction coefficient. In this condition, it is recommended to use circular protrusion in the rubber surface. The friction behavior of ceramic tiles, as floor materials when soft and hard rubbers slide against them, was described, [16]. Based on the experiments, it was found that at dry sliding soft rubber showed higher friction coefficient than hard one. The difference might be attributed to the extra deformation offered by soft rubber. Friction coefficient and electrostatic charge of epoxy composites filled by iron nanoparticles sliding against rubber to develop proper materials to be used as floor materials of high friction coefficient and low electrostatic charge were investigated, [17]. It was found that presence of sand particles on the sliding surfaces strongly affected the friction coefficient. Presence of sand decreased the electric static charge. The effect, of the filling materials on the friction coefficient of recycled rubber floors, was discussed, [18]. It was found that friction coefficient slightly increased with increasing the content of the filling materials. The lowest friction values were observed for tiles filled by 70 wt. \% polyurethane. The porous recycled rubber tiles were inspected to be used for architectural applications as floor tiles, [19]. It was found that friction coefficient displayed by bare foot sliding against dry recycled rubber tiles slightly increased with increasing force reduction ratio. It seems that the presence of pores inside the rubber matrix is responsible for the extra deformation displayed by the porous recycled rubber and consequently the contact area between the foot and the tested floor materials increased. The friction coefficient, of rubber semi-spherical balls of different diameter and hardness, was tested, [20]. Friction coefficient drastically decreased with increasing hardness when sliding against water, detergent and oil lubricated rubber. It showed significant increase with increasing the diameter of the semi-spherical protrusions. The effect, of the hardness and thickness of recycled rubber floor tiles on the friction coefficient, was tested, [21]. Based on the experimental observations, it was found that friction coefficient, displayed by sliding of rubber sole against dry floor tiles, drastically decreased with increasing the hardness of the tested floor tiles, while increased with increasing normal load. Friction coefficient of rubber sliding against polymeric indoor floor materials of different surface roughness was investigated under the following conditions: dry, water, water and soap, oil, water and oil, [22, 23]. It was found that, maximum friction values were observed at surface roughness ranging from 1.5 and 2.0 $\mu \mathrm{m}$ Ra. At water-soap lubricated sliding, the friction coefficient drastically decreased with increasing the surface roughness. At oil lubricated sliding, the maximum friction values were noticed at $4.0 \mu \mathrm{m}$ Ra surface roughness. At water and oil lubricated sliding, smooth floor surface displayed very low values of friction coefficient (0.08) close to the ones observed for mixed lubrication where the two sliding surfaces are partially separated by a fluid film. The effect of surface roughness on the friction coefficient of ceramic rubbing against rubber and 
leather, was investigated, [24]. Friction coefficient of glazed ceramic floor decreased down to minimum then increased with increasing the surface roughness of the ceramic surface. Bare foot sliding against epoxy floor showed relatively lower voltage than that displayed by rubber footwear, where the maximum value reached 280 volts, [25]. Rubber footwear sliding against epoxy floor displayed consistent trend of friction coefficient with increasing load. The highest friction coefficient value was 0.86 , while the lowest was 0.58 . Sliding against PVC floor experienced lower friction coefficient than that observed on epoxy floor. Recently, the effect of reinforcing epoxy by carbon fibres (CF), and coating by polyurethane on the friction coefficient displayed by contact and separation as well as sliding of bare foot and foot wearing rubber contacting epoxy was discussed, [26, 27]. It was observed that ESC increased with increasing CF content. Besides, as the CF were close to the sliding surface ESC increased. It is known that the strength of the electric field inside the epoxy matrix is proportional to how much charge is generated on the friction surface. The significant ESC increase when the CF were close to the surface confirmed the presence of a magnetic field around the CF that is directly proportional to the current value and inversely proportional to the distance from the conductor. ESC generated during contact and separation as well as sliding of insulating materials can play a major role in adhesion energy and alter friction. Reinforcing epoxy by carbon fibres (CF) and coating by polyurethane gave higher ESC and friction coefficient than that generated by epoxy. The aim of the present work is to investigate the effect of ESC generated from the contact and separation as well as sliding of bare foot and rubber footwear against epoxy floor reinforced by CF and coated by polyurethane (PU) contaminated by sand particles on friction coefficient.

\section{EXPERIMENTAL}

Experiments were carried out using test rig which shown in Figure 1 and Figure 2. It consists, mainly, of two load cell one places in horizontal position and other places in vertical position (horizontal load cell measured normal load while vertical one measured friction load). Also it consists of upper base that will covered by the flooring surface and lower base used to make test rig fixed on floor and not move during test running. Two monitors are connected to two load cell for reading normal and friction force. The effect of the tested parameters on friction coefficient of epoxy reinforced by carbon fibres (CF) such as content and distance from epoxy surface has been investigated. Epoxy test specimens have been prepared in the form of square sheets of $50 \times$ $50 \mathrm{~mm}$. The values of CF content used in experiment are $0,2,4,6,8$ wt. $\%$ as illustrated in Figure 3. Epoxy surface was coated by polyurethane (PU) coating of 0.5 $\mathrm{mm}$ thickness. Before drying, sand particles of $50-70 \mu \mathrm{m}$ particle size were hindered on PU coating. ESC measurement has been carried out. First, the tested surfaces were cleaned to eliminate any dirt and dust and carefully dried before the test. The test specimens have been loaded against human skin and rubber at contact and separation as well as sliding conditions. During test running, horizontal and vertical load cell connected to two monitors read normal and friction load respectively. Friction coefficient is the ratio between friction and normal load. By taking five values for each test the values of friction coefficient can be calculated. 


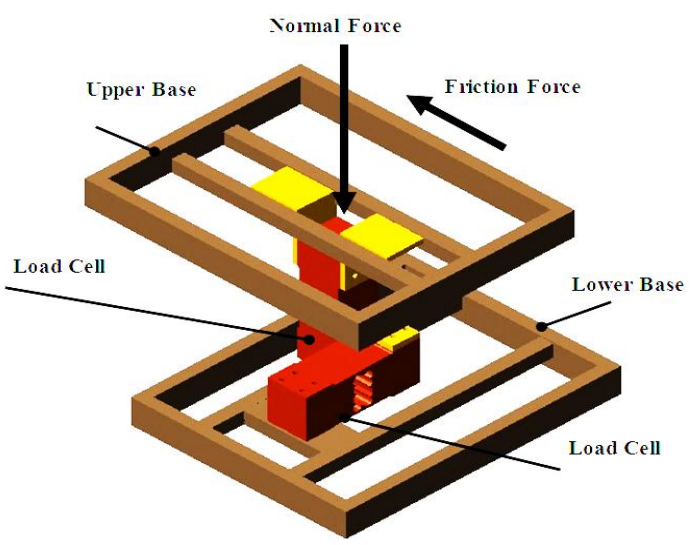

Fig.1. Details of the test rig.

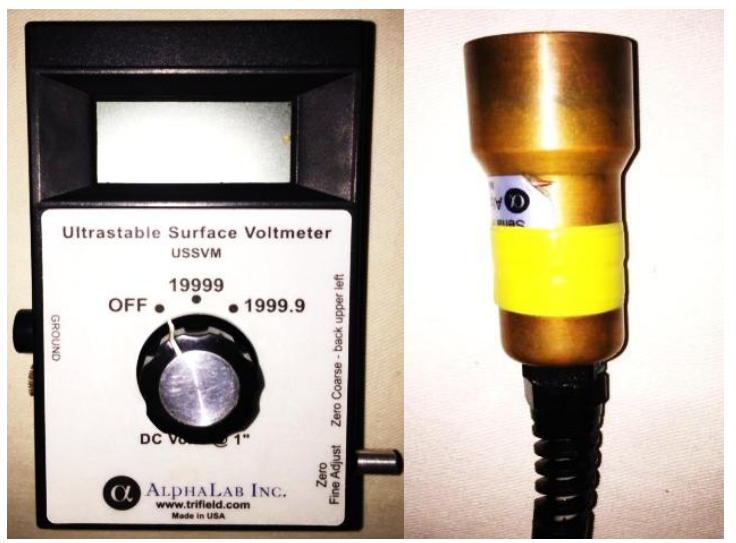

Fig.2. ESC measurement device.

\section{Distance from Surface}

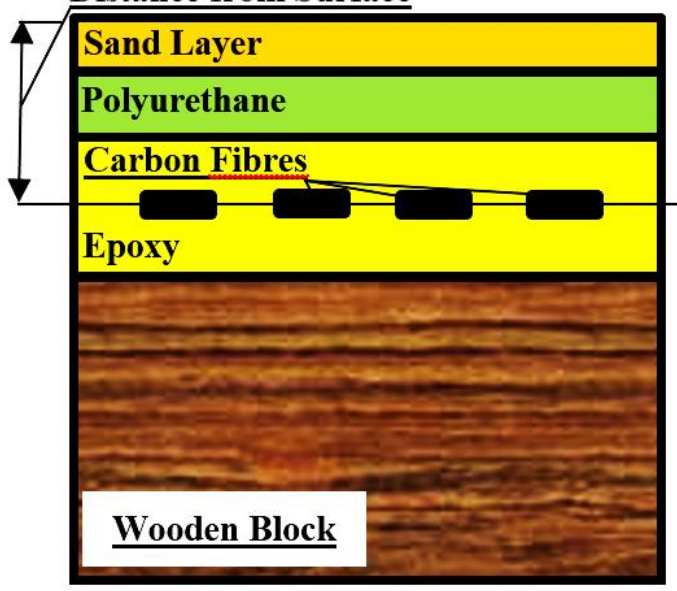

Fig.3. Test specimen used in experiments.

\section{RESULTS AND DISCUSSION}

ESC generated from contact and separation of PU coated by sand particles ( $\mathrm{SiO} 2)$ and reinforced by $\mathrm{CF}$ and bare foot is shown in Figures 4 to 6 . It is clearly shown that, increasing CF and normal load remarkably increased ESC. The highest and lowest ESC values (335 and 290 volts) were recorded for CF located at 1.0 and $5.0 \mathrm{~mm}$ far from the friction surface respectively. ESC recorded much higher values than $\mathrm{PU}$ and epoxy surfaces. As the difference in the rank of the two materials increases the generated ESC increases. It is known that sand is ranked as negative charged material relative to bare foot that is ranked as positive charged. Slight decrease in ESC was observed as the distance of CF from friction surface increased.

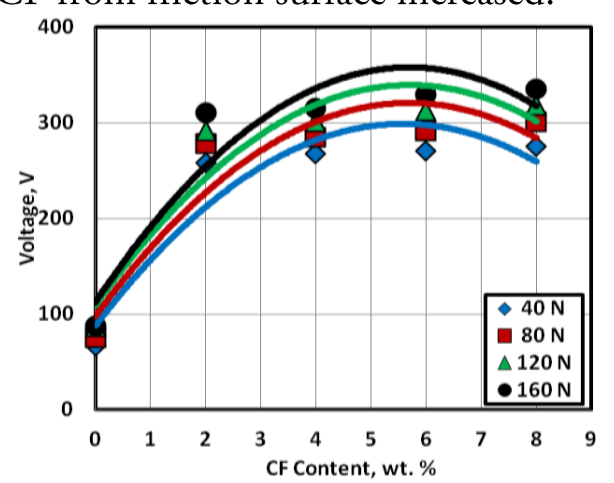

Fig. 4. ESC generated from contact and separation of bare foot and

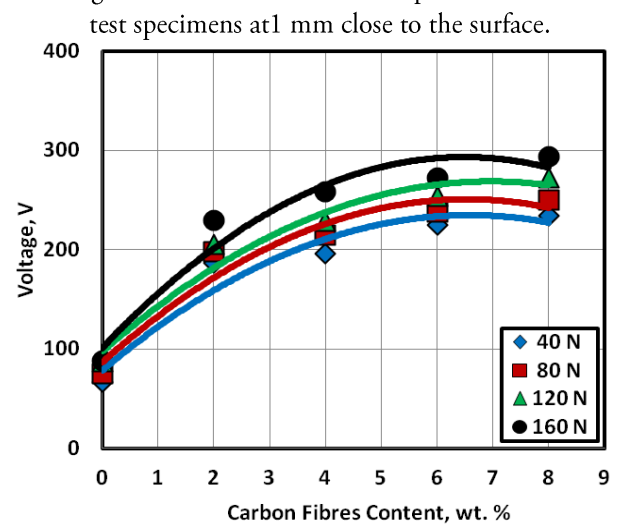

Fig. 5. ESC generated from contact and separation of bare foot and test specimens at $5 \mathrm{~mm}$ close to the surface.

ESC generated from sliding of PU coated by sand against bare foot, Figures 7 to 9, displayed relatively higher values than that measured for epoxy and PU surfaces. Presence of sand increases friction coefficient due to the abrasive action of particles in bare foot surfaces which increases ESC. The penetration of sand particles into bare foot increases the contact area and hence increases ESC. The highest and lowest 
voltage values (1600 and 420 volts) were recorded for composites reinforced by $\mathrm{CF}$ located at 1.0 and $5.0 \mathrm{~mm}$ far from the friction surface respectively. Drastic decrease in ESC was observed as the distance of CF from friction surface increased is shown in Figure 9.

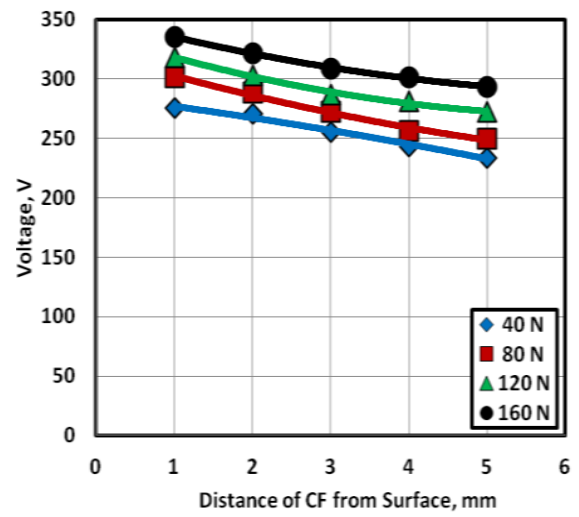

Fig. 6. Effect of the distance of CF from the surface on ESC generated from contact and separation of bare foot and test specimens.

The effect of CF location, relative to the sliding surface, on friction coefficient is shown in Figure 10. It seems that if CF were closer to the surface, they were strongly influenced by the electric field and consequently the intensity of the ESC increased. Friction coefficient values were 1.2 and 0.8 at 1 and $5 \mathrm{~mm}$ far from the surface respectively at $160 \mathrm{~N}$ load. This observation confirms the influence of the electric field on friction coefficient, where the values of friction can be controlled by varying the distance of CF from the epoxy surface, where the increase of the generated ESC caused an increase in the adhesive force between the two sliding surfaces and consequently increased friction. ESC generated from contact and separation of rubber footwear and PU coated by sand displayed lower values than that observed for bare foot, Figures 11 to 13. This behavior can be explained on the fact that sand particles could not penetrate rubber easily, so that the contact area was lower than experienced by bare foot. The highest value reached 235 volts. As the load increased voltage significantly increased. The effect of the location of CF on ESC has the same trend observed for previous experiments. The highest and lowest voltage values were recorded for CF located at 1.0 and $5.0 \mathrm{~mm}$ far from the friction surface respectively. Significant decrease in ESC was observed as the distance of $\mathrm{CF}$ from friction surface increased is shown in Figure 13. ESC slightly increased with increasing load. When CF were closer to the surface, the ability of the surface to generate higher amount of ESC increased. ESC was 240 and 135 volts in epoxy reinforced by CF at 1 and $5 \mathrm{~mm}$ far from the surface respectively.

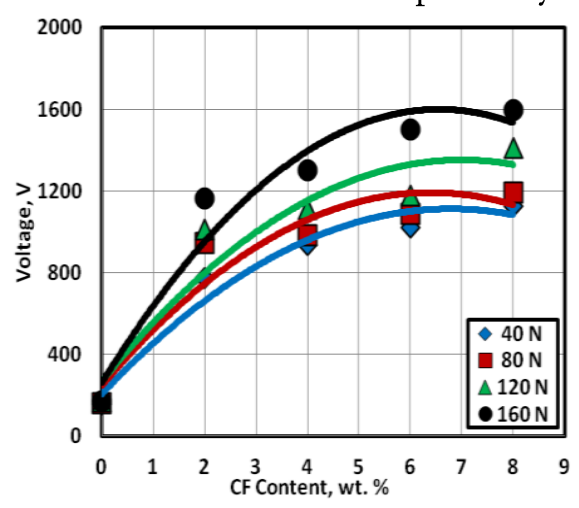

Fig. 7. ESC generated from sliding of bare foot and test specimens at $1 \mathrm{~mm}$ close to the surface.

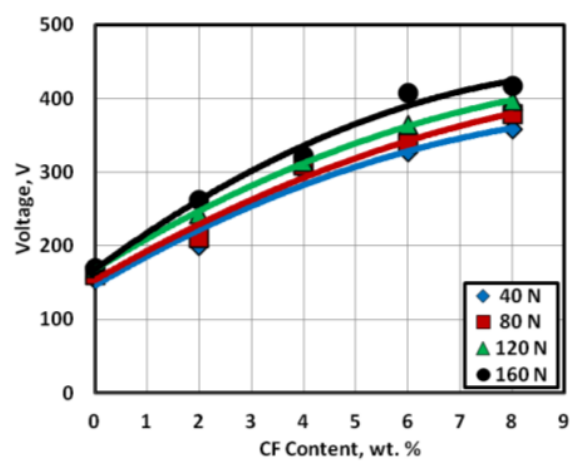

Fig. 8. ESC generated from sliding of bare foot and test specimens at $5 \mathrm{~mm}$ close to the surface. 


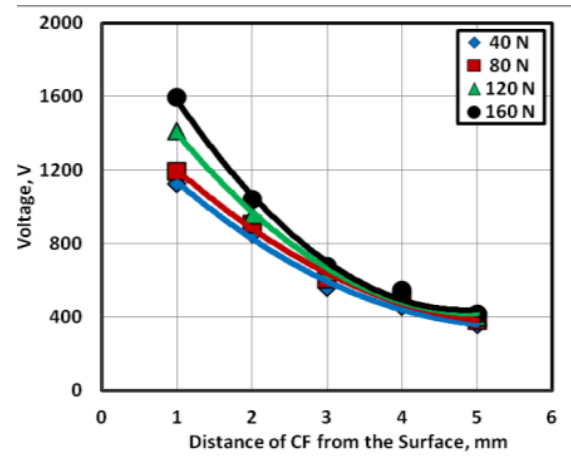

Fig. 9. Effect of the distance of CF from the surface on the electrostatic charge generated from sliding of bare foot against test specimens.

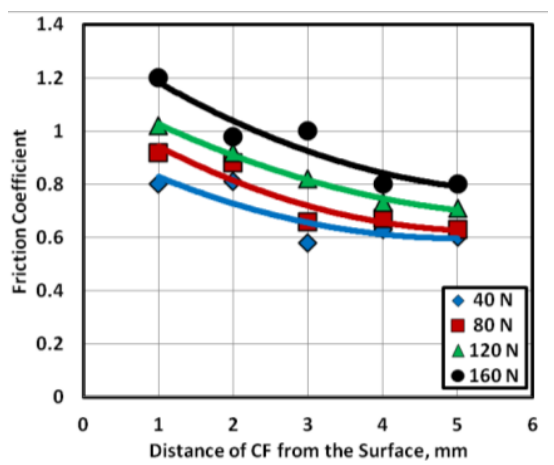

Fig. 10. Effect of the distance of CF from the surface on the friction coefficient displayed by sliding of bare foot against test specimens.

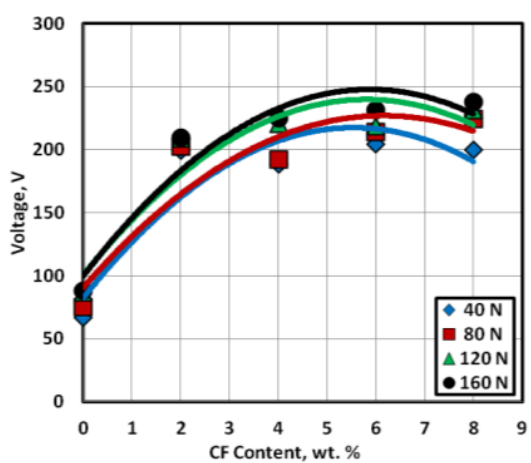

Fig. 11. ESC generated from contact and separation of rubber and test specimens at $1 \mathrm{~mm}$ close to the surface.

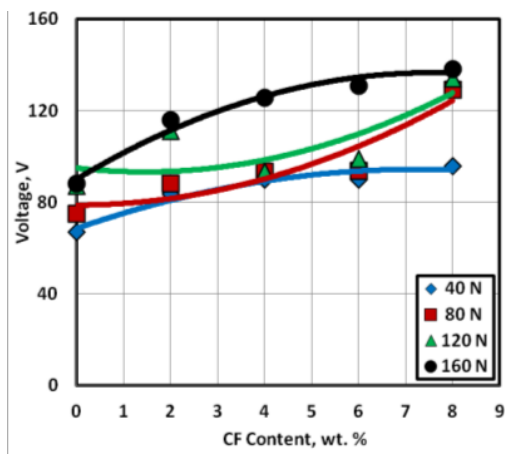

Fig. 12. ESC generated from contact and separation of rubber and test specimens at $5 \mathrm{~mm}$ close to the surface.

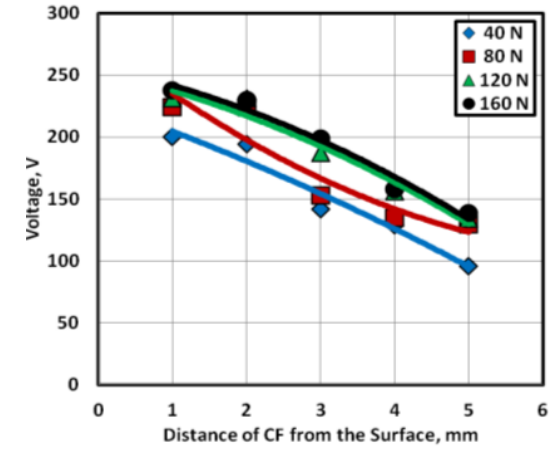

Fig. 13. Effect of the distance of CF from the surface on ESC generated from contact and separation of rubber and test specimens.

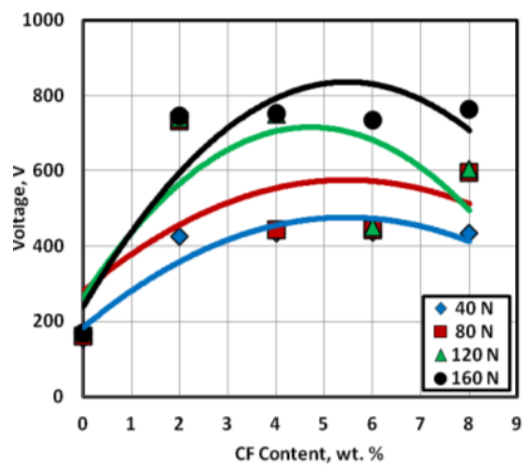

Fig. 14. ESC generated from sliding of rubber and test specimens at $1 \mathrm{~mm}$ close to the surface.

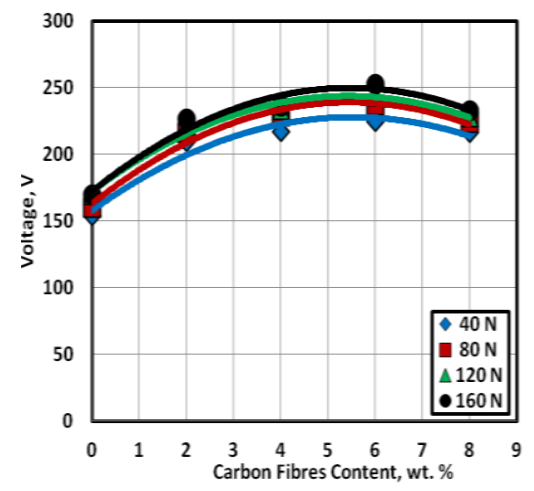

Fig. 15. ESC generated from sliding of rubber and test specimens at $5 \mathrm{~mm}$ close to the surface.

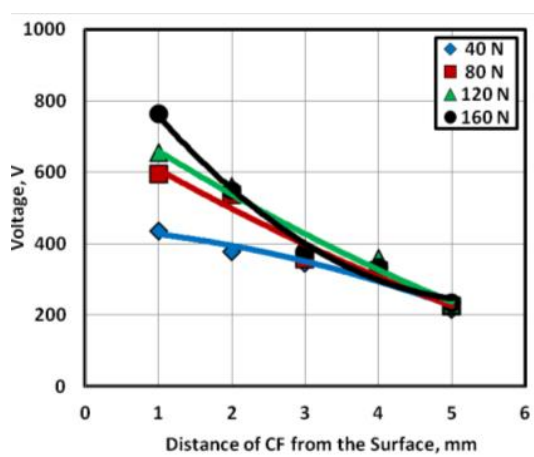

Fig. 16. Effect of the distance of CF from the surface on ESC generated from sliding of rubber and test specimens. 


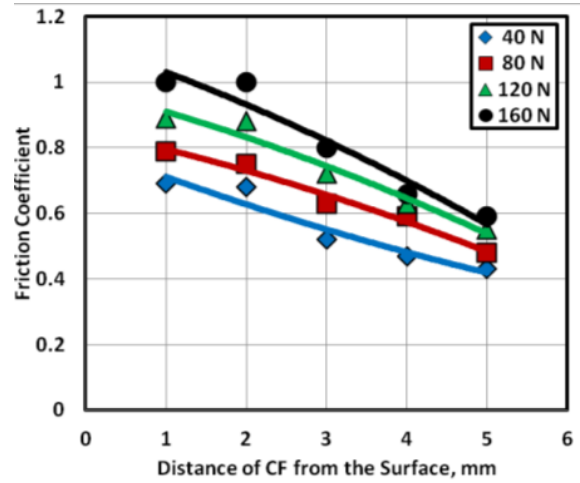

Fig. 17. Effect of the distance of CF from the surface on friction coefficient displayed by sliding of rubber against test specimens.

In condition of sliding of PU coated by sand and reinforced by $\mathrm{CF}$ against rubber, Figures 14 to 16 , it was found that increasing normal load and CF content caused significant ESC increase. ESC displayed values higher than that observed for contact and separation. The highest and lowest voltage values (770 and 230 volts) were recorded for CF located at 1.0 and $5.0 \mathrm{~mm}$ far from the friction surface respectively. It was noticed that when CF were closer to the surface the ability of wires to conduct ESC increased. The influence of sand was more pronounced during sliding than contact and separation. ESC decreased as the distance of $\mathrm{CF}$ from friction surface increased, Figure 16. The results of the experiments carried out to test the friction coefficient from the sliding of PU coated sand against rubber is shown in Figure 17. Friction coefficient decreased with increasing the distance from the surface. The lowest friction value was 0.8 , while the highest value was 1.2 at $160 \mathrm{~N}$ normal load. As the load increased, friction coefficient slightly increased. The friction values guaranteed the good adhesion required for floor materials.

\section{CONCLUSION}

1. ESC generated from contact and separation as well as sliding of PU coated by sand particles against bare foot recorded much higher values than PU/epoxy contact. Presence of sand increases friction coefficient due to the abrasive action of particles in bare foot surfaces. The penetration of sand particles into bare foot increases the contact area and hence increases ESC.

2. Contact and separation with rubber generated displayed lower values than that observed for bare foot, while sliding showed that influence of sand was more pronounced. Friction coefficient displayed by rubber sliding against epoxy represented the highest values at relatively higher loads.

3. Friction coefficient depends on the amount of ESC generated from triboelectrification.

\section{REFERENCES}

[1] El-Sherbiny Y. M., Mohamed M. K., Ali W. Y., "Friction Coefficient Displayed by Footwear Walking Against Rubber Floors Fitted by Cylindrical Treads", Journal of the Egyptian Society of Tribology, Vol. 8, No. 1, January 2011, pp. 1 - 12, (2011).

[2] Miller J. M., "“Slippery" work surface: toward a performance definition and quantitative friction coefficient criteria", J. Saf. Res. 14, pp. 145 158, (1983).

[3] Grönqvist R., "Mechanisms of friction and assessment of slip resistance of new and used footwear soles on contaminated floors", Ergonomics 38, pp. 224 - 241, (1995).

[4] Myung, R., Smith, J. L., Leamon, T. B., "Subjective assessment of floor slipperiness", Int. J. Ind. Ergon. 11, pp. 313 - 319, (1993).

[5] Kai W. L., Rui-feng Y., Xiao L. H., "Physiological and psychophysical responses in handling maximum acceptable weights under different footwear-floor friction conditions", Applied Ergonomics 38, pp. 259 - 265, (2007).

[6] Burnfield J. M., Tsai Y. J., Powers Ch. M., "Comparison of utilized friction coefficient during different walking tasks in persons with and without a disability', Gait \& Posture 22, pp. $82-88$, (2005). 
[7] Elham B. R., Khashaba M. I. and Ali W. Y., "Effect of Surface Roughness on Friction Coefficient of Recycled Rubber Floors", Journal of the Egyptian Society of Tribology Vol. 10, No. 1, January 2013, pp. $13-25$, (2013).

[8] El-Sherbiny Y. M. Ramadan M. A. and Ali W. Y., "Frictional Behaviour of Rubber Floor Mat Fitted by Rectangular Treads", Journal of the Egyptian Society of Tribology, Vol. 11, No. 2, April 2014, pp. 39 - 52, (2014).

[9] El-Sherbiny Y. M., Hasouna A. T. and Ali W. Y., "Friction Coefficient of Rubber Sliding Against Floor Materials", ARPN Journal of Engineering and Applied Sciences, VOL. 7, NO. 1, January 2012, pp. 1 - 7, (2012).

[10] El-Sherbiny Y. M., Abdel-Jaber G. T. and Ali W. Y., "Friction Coefficient and Electrostatic Charge Generated From Rubber Footwear Sliding Against Floor Materials", Journal of the Egyptian Society of Tribology, Vol. 11, No. 4, October 2014, pp. 13 - 24, (2014).

[11] Samy A. M., Khashaba M. I. and Ali W. Y., "Influence of Grooves on Friction Coefficient displayed by Rubber Disc Sliding against Ceramics", KGK Kautschuk Gummi Kunststoffe 11-12 2014, pp. 52 - 56, (2014).

[12] Samy A. M., Khashaba M. I. and Ali W. Y., "Friction Coefficient of Grooved Rubber Disc Sliding Against Ceramics: I. Effect of Motion Direction", Journal of the Egyptian Society of Tribology, Vol. 11, No. 2, April 2014, pp. 1 20, (2014).

[13] Samy A. M., Khashaba M. I. and Ali W. Y., "Friction Coefficient of Grooved Rubber Disc Sliding Against Ceramics: II. Effect of Load", Journal of the Egyptian Society of Tribology, Vol. 11, No. 2, April 2014, pp. 21 - 38, (2014).

[14] Samy A. M., Khashaba M. I. and Ali W. Y., "Friction coefficient of grooved rubber disc sliding against ceramics: III. Effect of the Grooves", Journal of the Egyptian Society of Tribology, Vol. 11, No. 3, July 2014, pp. 1 19, (2014).

[15] El-Sherbiny Y. M., Samy A. M. and Ali W. Y., "Friction Coefficient of Rubber Sliding Against Dusty Indoor Floor", KGK Kautschuk Gummi Kunststoffe 62. Jahrgang, Nr 622, March 2012, (2012).
[16] Mohamed M. K., ElKattan A. A. and Ali W. A., "Friction Coefficient Displayed by Rubber Sliding Against Floor Tiles", International Journal of Engineering \& Technology IJETIJENS Vol:12 No:06, pp. 144 - 149, (2012).

[17] El-Sherbiny Y. M., Ibrahim R. A. andand Ali W. Y., "Effect of sand on the friction coefficient displayed by rubber sliding against epoxy floors filled by iron nanoparticles", Journal of the Egyptian Society of Tribology, Vol. 11, No. 3, July 2014, pp. 45 - 59, (2014).

[18] Elham B. R., Khashaba M. I. and Ali W. Y., "Effect of Filling Materials on the Friction Coefficient of Recycled Rubber Floor", Journal of the Egyptian Society of Tribology Vol. 10, No. 1, January 2013, pp. 1 - 12, (2013).

[19] Samy A. M., El-Sherbiny Y. M. and Ali W. Y., "Friction Coefficient of Recycled Rubber Tiles of Different Porosity", Journal of the Egyptian Society of Tribology Vol. 10, No. 1, January 2013, pp. 38 - 49, (2013).

[20] El-Sherbiny Y. M., Al-Qaham Y. G. and Ali W. Y., "Friction Coefficient of Semi-Spherical Rubber Protrusions Sliding Against Rubber", Journal of the Egyptian Society of Tribology Vol. 10, No. 3, July 2013, pp. 1 - 12, (2013).

[21] Mai K. M., Khashaba M. I., Mousa M. O. and Ali W. Y., "Friction Coefficient Displayed by Sliding of Rubber Sole Against Recycled Rubber Floor Tiles", EGTRIB Journal, Vol. 12, No. 4, October 2015, pp. 28 - 39, (2015).

[22] Ezzat F. H., Hasouna A. T. and Ali, W., "Effect of Surface Roughness of Indoor Floor Materials on Friction Coefficient", KGK, January 2008, pp. 42 - 49, (2008).

[23] Ezzat, F. H., Hasouna, A. T. and Ali, W. Y., "Friction Coefficient of Rubber Sliding Against Polymeric Indoor Floor Materials of Different Surface Roughness", KGK Kautschuk Gummi Kunststoffe 61. Jahrgang, $\mathrm{Nr}$ 608, December 2008, pp. 638 - 641, (2008).

[24] Ezzat, F.H., Abdel-Jaber, G.T. and Ali, W.Y., Dry Sliding of Rubber on Glazed Ceramic Tiles, Proceedings of the 7 th International Conference of Tribology, EGTRIB 7, December 27 - 28, 2006, Faculty of Engineering, Cairo University, CI, 1-9 (2006).

[25] Elhabib O. A., Mohamed M. K., AlKattan A. A. and Ali W. Y., "Triboelectrification of Floor Polymeric Materials", International Journal of 
Scientific \& Engineering Research,Volume 5, Issue 6, June 2014 , pp. 248 - 253, (2014).

[26] Ali A. S. and Khashaba M. I., "Friction Behavior of Carbon Fibres Reinforced Epoxy Floor", Journal of the Egyptian Society of Tribology Vol. 15, No. 1, January 2018, pp. 1 $-20,(2018)$.
[27] Ali A. S. and Khashaba M. I., "Friction Behavior of Carbon Fibres Reinforced Epoxy Floor and Coated by Polyurethane", Journal of the Egyptian Society of Tribology Vol. 15, No. 1, January 2018, pp. 21 - 37, (2018). 
سلوك الإحتكاك لأرضيات الإيبوكسي المقواة بالياف الكربون والمغلفة بطبقة من البولي اوريثان والرمل

$$
\text { 1 شركة بيتروجيت، أ. ساهرة، مصر. }
$$

2 قسم هنسة الإنتاج و التصميم الميكانيكي، كلية الهنسة، جامعة المنيا، المنيا، مصر

الملخص:

يقدم هذا البحث دراسة عن معامل الاحتكاك الناتج من تماس و انفصال وكذلك انزلاق القدم العارية والحذاء المطاطى على بلاطة الايبوكسي المقواة بألياف الكربون والمغلفة بطبقة من البولي أوريثان والرمل. كما تم در اسة تولد الثحنة الكهربية الساكنة نتيجة الإحتكاك وتأثير ذلك على معامل الاحتكالك. وقد وجد أن الثحنة الكهربية الساكنة التى تولدت من تماس وانفصال السطح المغلف بجزيئات الرمال و المقوى بألياف الكربون سجلت قيما أعلى بكثير من سطح الايبوكسي الغير مغلف. كما لوحظ انخفاض طفيف في الثحنة الكهربية الساكنة كلما بعدت ألياف الكربون من سطح الاحتكاك. كذلك وجد أن الثحنة الكهربية الساكنة الناتجة من انزلاق القدم العارية على البولى أوريثان و الرمل عرضت قيماً أعلى نسبياً من تللك التي قيست للأيبوكسي المغطى بالبولى أوريثان. كما تبين أن وجود الرمال زاد من معامل الاحتكالك بسبب إنغماس حبيات الرمال في سطح القدم العارية وكذللك زاد من مما يزيد الثحنة الكهربية الساكنة . كما لوحظ أن إنغماس حبيبات الرمال للقدم العارية قد زاد من مساحة التلامس وبالتالي زاد من الثحنة الكهربية الساكنة. وسجل معامل الاحتكاك قيماً أعلى نسبياً من القيم المسجلة للإيبوكسي المغطى بالبولى أوريثان. كذلك وجد أن الثحنة الكهربية الساكنة المتولدة من التلامس والإنفصال للأحذية المطاطية والبولى أوريثان المغطى بالرمال عرضت قيماً أقل من تلك التي لوحظت للقدم العارية. وفي حالة انزلاق الأحذية المطاطية على البولى أوريثان المغطاة بالرمال وجد أن الثحنة الكهربية الساكنة عرضت قيماً أعلى من تلك التى لوحظت في التلامس والإنفصال حيث كان نأثثر الرمال أكثر وضوحاً. كما انخفض معامل الاحتكاك مع زيادة بعد موقع ألياف الكربون من السطح. كذللك كانت قيم معامل الاحتكاك عالية بالدرجة التى تضمن التصاقاً جيداً للقدم مع بلاطة الاييوكسي المقواة بألياف الكربون و المغلفة بطبقة من البولي أوريثان و الرمل. 